\title{
Incidence of Cytomegalovirus Antigenemia in patients with autoimmune rheumatic diseases: a 3-year retrospective study
}

\author{
Rebeka Paulo Santos ${ }^{1}$ (D), Edgard Torres dos Reis-Neto ${ }^{1}$ (D) and Marcelo Medeiros Pinheiro ${ }^{1,2^{*}}$ (D)
}

\begin{abstract}
Objective: To determine the incidence of positive CMV antigenemia (CMV-Ag) in patients with autoimmune rheumatic diseases (AIRD) and to describe the outcomes of these patients.

Methods: From January 2011 to December 2014, a total of 443 patients with AIRD were enrolled in this retrospective analysis. Demographic, clinical and laboratory data, current clinical manifestations, organs affected by CMV infection, therapeutic management and outcomes were evaluated. The CMV-Ag was considered positive when one cell was detected at least.

Results: CMV-Ag was requested in 70 (15.8\%) patients with suspicious CMV infection and was positive in 24 (34. 3\%). The incidence rate of positive CMV-Ag was 4.97\% (95\% Cl 3.1-7.4\%). Systemic lupus erythematosus (SLE) (59\%), followed by ANCA-related vasculitis (18.2\%) and rheumatoid arthritis (9\%) were the diseases more associated with positive CMV-Ag. At the time of CMV infection, SLE patients had moderate to severe disease activity, with high frequency of positive anti-dsDNA antibody (69.2\%) and complement consumption (61.5\%), as well as high doses of corticosteroids and use of immunosuppressants. The main CMV sites involved were lung (45.5\%), bone marrow (40. 9\%) and gut (27.3\%). Mortality rate was $45.5 \%$, especially in those with higher doses of daily oral corticosteroids $(107 \pm 55.4 \mathrm{mg}$ vs. $71.7 \pm 46.3 \mathrm{mg} ; p=0.07)$ and lower number of lymphocytes $\left(309 \pm 368.2 / \mathrm{mm}^{3}\right.$ vs. $821 \pm 692.9 /$ $\left.\mathrm{mm}^{3} ; p=0.06\right)$.

Conclusions: Our data showed high incidence of CMV-Ag in AIRD patients, particularly those with SLE and greater disease severity. In addition, it was observed high mortality in these patients, highlighting the CMV infection should be included in differential diagnosis.
\end{abstract}

Keywords: Cytomegalovirus, Infection, Antigenemia, Autoimmunity, Incidence

\section{Introduction}

Cytomegalovirus (CMV) is related to opportunistic infections in immunocompromised patients with autoimmune rheumatic diseases (AIRD) $[1,2]$. Several studies have highlighted its pathogenic role in triggering or hampering some AIRD [3]. In immunocompromised individuals, the reactivation of latent $\mathrm{CMV}$ infection may cause fever, chills, weight loss, asthenia, hematological disorders (anemia, leukopenia, and thrombocytopenia) or severe symptomatic

\footnotetext{
* Correspondence: mpinheiro@uol.com.br

${ }^{1}$ Division of Rheumatology, Universidade Federal de São Paulo, São Paulo, SP, Brazil

${ }^{2}$ Disciplina de Reumatologia, Escola Paulista de Medicina - Universidade Federal de São Paulo, Rua Leandro, Dupré, 204, conjunto 74, Vila Clementino, São Paulo, SP 04025-010, Brazil
}

organ involvement, including hepatitis, chorioretinitis, encephalitis, pneumonitis and digestive hemorrhage [4].

The CMV antigenemia (CMV-Ag) is the main method for the diagnosis of infection due its high sensitivity (91\%) and specificity (95\%), as well as early and fast detection and therapeutic monitoring by number of affected cells [3]. On the other hand, it has some limitations, such as neutropenia below $1000 / \mathrm{mm}^{3}$ (false-negative) and other tests should be necessary for a better diagnosis $[5,6]$.

There are some epidemiological data and management guidance addressed to immunosuppressed patients, including AIDS and after solid organ and bone marrow transplantation [7-11]. However, there is a lack of evidence in patients with AIRD and the recommendations 
for managing these patients are extrapolated from transplantation data [12].

Thus, the aim of this study was to evaluate the incidence of CMV-Ag and describe the main outcomes over time in AIRD patients.

\section{Patients and methods}

\section{Patients}

Patients admitted to the rheumatology service at a tertiary university hospital in São Paulo/ SP, Brazil, from 01/JAN/ 2011 to 31/DEC/2014, were analyzed and those with clinical CMV suspicion infection and positive CMV-Ag for one cell, at least, were included. A total of 443 patients with AIRD were enrolled in this retrospective analysis. $\mathrm{Pa}-$ tients with other viral infections, including hepatitis $\mathrm{B}$ and $\mathrm{C}$, HIV, and Epstein-Barr were excluded. The positive CMV-Ag was defined when one cell was detected at least.

\section{Clinical evaluation}

Demographic, clinical and laboratory data were recorded for all patients. Specific details of each AIRD and current clinical manifestations, including disease activity, organs affected by CMV infection, therapeutic management (initial and secondary prophylaxis) and outcomes were also explored. For assessment of disease activity were used the Systemic Lupus Erythematosus Disease Activiy Index (SLEDAI) for SLE [13] and Birmingham Vasculitis Activity Score (BVAS) for ANCA associated vasculitis [14].

\section{Laboratory evaluation of the CMV viremia}

CMV-pp65 antigen detection was undertaken by the monoclonal antibody indirect immunofluorescence (IF) method (CMV Brite Turbo Kit, IQ Products, Gronigen, The Netherlands). The number of leukocytes stained positive every 200,000 neutrophils in peripheral blood was then documented.

Quantitation of CMV-DNA was undertaken by real-time fluorescence quantitative polymerase chain reaction (RTPCR-fluorecence) technology (CMV nuclei acid quantitative assay kit, TaqMan Roche - FAM, Branchburg, USA) when available. The criteria for positive result was CMV-DNA $\geq 500$ copies/ml. Viral inclusion bodies found in the tissue biopsy, stained with hematoxylin-eosin, were also considered positive for CMV infection.

\section{Definition of CMV disease and follow-up protocol}

Patients with laboratory abnormalities (anemia, leukopenia, thrombocytopenia or liver enzymes) or clinical manifestations, such as fever, gut or eye symptoms or lung injury, excluding other infection causes, were considered as suspicious symptomatic for CMV infection. CMV disease was defined when the confirmation had been performed by biopsy and identification of positive viral inclusion corpuscles or immunohistochemistry of affected organ.
After treatment with antivirals, patients had CMV-Ag repeated weekly until becoming negative. This outcome was defined as improvement of CMV infection.

\section{Statistical analysis}

All analyses were proceeded using SPSS 20.0 (IBM, New York, USA). Shapiro-Wilk or Kolmogorov-Smirnov tests were applied to assess the normality of the variables. To compare continuous variables, Student-t test or Mann-Whitney test were used. Pearson and Spearman correlation tests were used to analyse the correlation between variables. Categorical data were analyzed by chi-square test or Fisher's exact test. Significant variables in the univariate analysis or correlation tests were used for tailoring the multivariate regression models in which the positive $\mathrm{CMV}-\mathrm{Ag}$ was considered as dependent variable and all other as independent, in order to explore main prognostic factors. Besides, ROC analysis was performed to determine the absolute cut-off value of the positive CMV-Ag related to death. $P$ value below 0.05 was set as significant.

This study was approved by the Ethics and Research Committee of Hospital São Paulo / Unifesp (506.406).

\section{Results}

From 443 patients with AIRD hospitalized in a tertiary university center, the CMV-Ag was requested to 70 (15.8\%) patients with suspicious CMV infection and it was positive in $24(34.3 \%)$.

Two positive CMV-Ag were excluded because one patient had cutaneous lupus (not systemic) and the other had Behcet's disease whose clinical manifestation of possible viral infection (acute diarrhea) was attributed later to adverse event by using of colchicine. Thus, 22 patients with AIRD and positive CMV-Ag were evaluated (Fig. 1). The incidence global rate of the positive CMV-Ag was $4.97 \%$ (95\% CI 3.1 to $7.4 \%$ ). Considering only lupus hospitalized patients, the CMV-Ag rate was $16.5 \%$ (95\% CI 9.7 to $51.9 \%$ ).

The main sites involved by CMV infection were lung, bone marrow and gut. Tables 1 and 2 show the main characteristics of AIRD patients with positive CMV-Ag. Lupus patients were younger than those with other AIRD (29.1 \pm 13.4 years vs. $54.2 \pm 21.1$ years; $p=0.03$ ). In addition, the majority of patients had high disease activity associated with severe infection, such as lupus patients (SLEDAI = $15.3 \pm 9)$ and patients with ANCA-associated vasculitis (BVAS $=5.2 \pm 3.8$ ).

The length of hospital stay (11.5 \pm 12 days) was long and there was a delay time between the beginning of symptoms and the CMV-Ag has been requested (7.8 \pm 7.1 days). Besides, 16 (72.7\%) patients had co-infections with other antimicrobial agents, such as Candida albicans and Acinetobacter baumannii, and there were five cases of polymicrobial infections. 


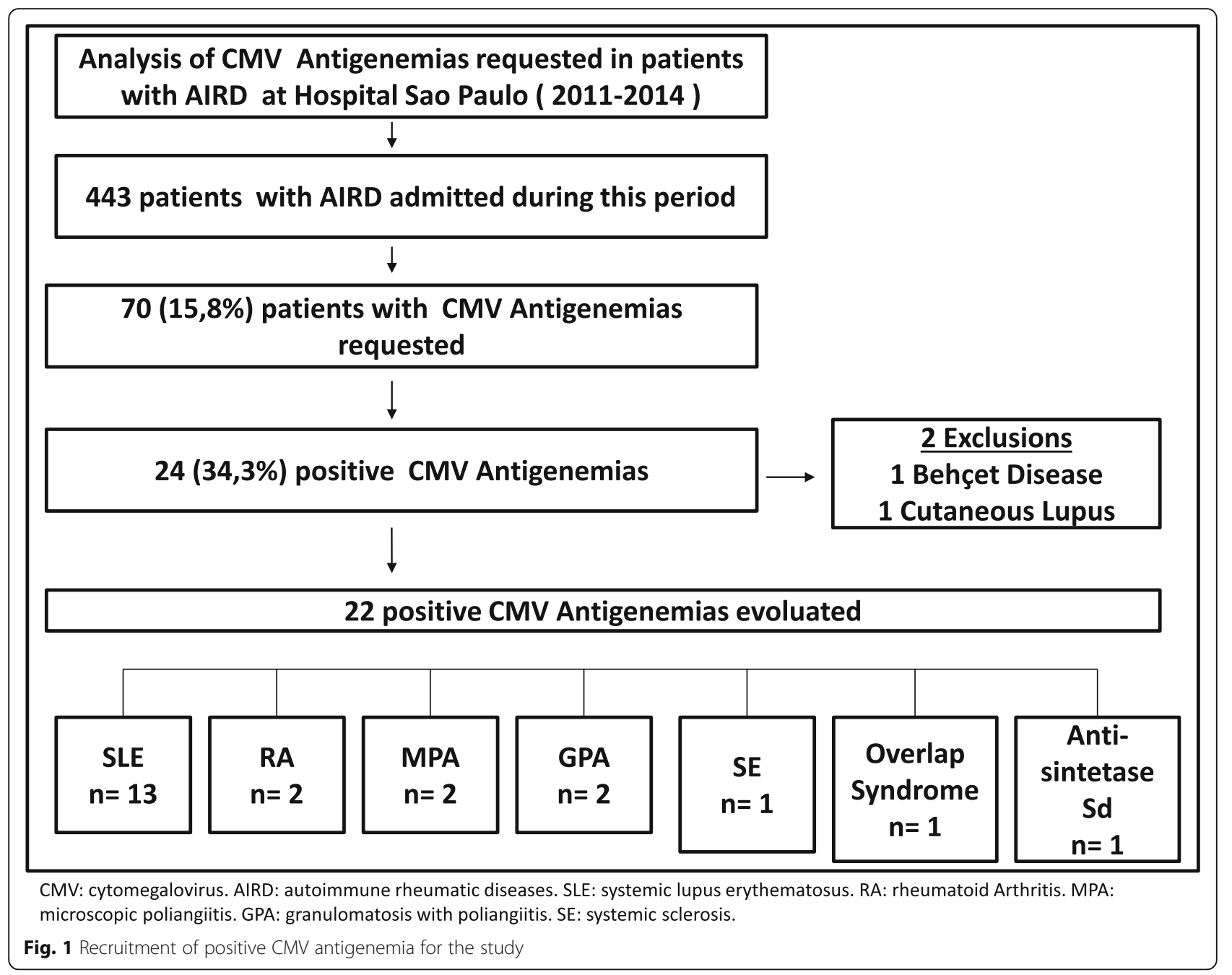

Regarding the treatment for AIRD, 19 (86.4\%) patients used corticosteroid (up to $1 \mathrm{mg} / \mathrm{kg} /$ day of prednisone or equivalent) and 11 (50\%) patients used other immunosuppressants drugs during hospitalization, including cyclophosphamide.

Concerning the treatment for CMV, 15 (68.2\%) of them received ganciclovir. In general, these patients tended to have more positive cells than those untreated [16 (1-500) vs. $1(1-4) ; p=0.05]$. Only three patients reported adverse events related to ganciclovir, including cutaneous and cytopenia reaction.

Lupus patients had greater number of positive CMV-Ag than other AIRD. These patients were using high doses of corticosteroids and had received methylprednisolone pulse therapy in the last 6 months prior to infection. Moreover, the median time of disease was only 12 months (0-276), suggesting higher likely of viremia and CMV involvement in early disease. They had higher predominance of joint, kidney and hematological involvement, as well as higher positivity for anti-dsDNA antibody (69.2\%) and complement consumption (61.5\%). Few lupus patients had cutaneous or neurological involvement.

The mortality rate was $45.4 \%$ (10 deaths in total: 4 in SLE patients; 3 in patients with ANCA-associated vasculitis, 1 patient had systemic sclerosis, 1 with RA and other with overlap syndrome). Three deaths were observed between the seven patients who did not receive specific treatment for CMV, although not significant.

After assessing the risk factors for death, there was no difference among patients who survived or died regarding to age, average number of positive cells on antigenemia, site of virus involvement, hospitalization, symptoms until the first CMV-Ag be requested and pulse therapy in the last 6 months. However, there was a tendency to higher doses of oral corticosteroids $(107 \pm 55.4 \mathrm{mg} /$ day vs. $71.7 \pm 46.3 \mathrm{mg} /$ day; $p=0.07)$ and lower number of lymphocytes when patients who died were compared to those who survived $\left(309 \pm 368.2 / \mathrm{mm}^{3}\right.$ vs. $821 \pm 692.9 / \mathrm{mm}^{3} ; p=0.06$ ). Moreover, the surviving patients remained hospitalized for longer time than those who died $(24.3 \pm 23.9$ days vs. $56.6 \pm 35.1$ days; $p=0.017$ ) (Table 3 ). 
Table 1 Clinical and laboratory data of 22 patients with autoimmune rheumatic disease (AIRD) and positive cytomegalovirus antigenemia

\begin{tabular}{|c|c|c|c|c|c|c|c|c|}
\hline Patient & $\begin{array}{l}\text { Age } \\
\text { (years)/ } \\
\text { Sex }\end{array}$ & AIRD & $\begin{array}{l}\text { Immunosuppressive } \\
\text { therapy in hospital }\end{array}$ & $\begin{array}{l}\text { Lymphocyte } \\
\text { Count }(/ \mu l)\end{array}$ & $\begin{array}{l}\text { Positive CMV } \\
\text { antigenemia nuclei } \\
\text { (/200.000PMN) }\end{array}$ & $\begin{array}{l}\text { Sites involved } \\
\text { by CMV } \\
\text { infection }\end{array}$ & Symptoms & Outcome \\
\hline 1 & $67 / F$ & SLE & $\begin{array}{l}\text { CFA, PDN } 130 \text { mg/ } \\
\text { day }\end{array}$ & 1311 & 32 & Gut & Esophageal ulcers & Death \\
\hline 2 & $34 / F$ & SLE & $\begin{array}{l}\text { AZA, CFA, PDN } 80 \\
\text { mg/day }\end{array}$ & 1356 & 1 & Lung & $\begin{array}{l}\text { Cough, dyspnea, } \\
\text { fever }\end{array}$ & Improvement \\
\hline 3 & $17 / F$ & SLE & PDN 200 mg/day & 444 & 2 & Cytopenia & $\begin{array}{l}\text { Neutropenia, } \\
\text { Thrombocytopenia }\end{array}$ & Improvement \\
\hline 4 & $22 / F$ & SLE & PDN 60 mg/day & 695 & 5 & Gut & Mouth ulcers & Improvement \\
\hline 5 & $21 / F$ & SLE & PDN 60 mg/day & 135 & 500 & $\begin{array}{l}\text { Cytopenia / } \\
\text { Lung }\end{array}$ & $\begin{array}{l}\text { Trombocyotpenia, } \\
\text { Cough, dyspnea, } \\
\text { fever }\end{array}$ & Death \\
\hline 6 & $25 / F$ & SLE & PDN 180 mg/day & 525 & 1 & Lung & $\begin{array}{l}\text { Cough, dyspnea, } \\
\text { fever }\end{array}$ & Death \\
\hline 7 & $16 / F$ & SLE & $\begin{array}{l}\mathrm{MP}+\mathrm{CFA}, \text { PDN } 50 \\
\mathrm{mg} / \text { day }\end{array}$ & 850 & 108 & Cytopenia & Febrile neutropenia & Improvement \\
\hline 8 & $20 / F$ & SLE & $\begin{array}{l}\mathrm{MP}+\mathrm{CFA}, \mathrm{PDN} 60 \\
\mathrm{mg} / \text { day }\end{array}$ & 792 & 1 & Gut & Esophageal ulcers & Improvement \\
\hline 9 & $38 / F$ & SLE & PDN 60 mg/day & 2751 & 2 & Lung & $\begin{array}{l}\text { Cough, dyspnea, } \\
\text { fever }\end{array}$ & Improvement \\
\hline 10 & $30 / F$ & SLE & $\begin{array}{l}\text { CFA, PDN } 60 \mathrm{mg} / \\
\text { day }\end{array}$ & 659 & 2 & Cytopenia & Pancytopenia, fever & Death \\
\hline 11 & $25 / F$ & SLE & $\begin{array}{l}\text { MMF, MP, PDN } 50 \\
\text { mg/day }\end{array}$ & 853 & 164 & Cytopenia & $\begin{array}{l}\text { Anemia, } \\
\text { Thrombocytopenia }\end{array}$ & Improvement \\
\hline 12 & $37 / F$ & SLE & PDN 60 mg/day & 80 & 46 & Cytopenia /Gut & Anemia, diarrhea & Improvement \\
\hline 13 & $26 / F$ & SLE & $\begin{array}{l}\mathrm{MP}+\mathrm{CFA}, \mathrm{PDN} 90 \\
\mathrm{mg} / \text { day }\end{array}$ & 714 & 2 & Lung & Cough, dyspnea & Improvement \\
\hline 14 & $77 / F$ & SE & - & 125 & 1 & Cytopenia & Pancytopenia, fever & Death \\
\hline 15 & 29/M & $\begin{array}{l}\text { Overlap } \\
\text { Sd. }\end{array}$ & PDN160mg/day & 246 & 16 & Lung & Cough, dyspnea & Death \\
\hline 16 & $70 / \mathrm{M}$ & RA & MP, PDN 20 mg/day & 77 & 1 & Cytopenia & Pancytopenia, fever & Improvement \\
\hline 17 & $17 / M$ & RA & PDN 160 mg/day & 689 & 1 & Lung & Cough, dyspnea & Death \\
\hline 18 & $42 / F$ & MPA & PDN 100 mg/day & 197 & 4 & Lung & $\begin{array}{l}\text { Cough, dyspnea, } \\
\text { Fever }\end{array}$ & Death \\
\hline 19 & $77 / F$ & MPA & PDN 100 mg/day & 372 & 500 & $\begin{array}{l}\text { Cytopenia / } \\
\text { Lung }\end{array}$ & $\begin{array}{l}\text { Anemia, Leukopenia, } \\
\text { Cough, Fever }\end{array}$ & Death \\
\hline 20 & $63 / F$ & GPA & $\begin{array}{l}\text { CFA, PDN } 30 \text { mg/ } \\
\text { day }\end{array}$ & 857 & 9 & Gut & Gastric ulcer & Improvement \\
\hline 21 & $58 / \mathrm{M}$ & GPA & $\begin{array}{l}\text { AZA, MP, PDN } 120 \\
\text { mg/day }\end{array}$ & 213 & 73 & Gut & Gastric ulcer & Death \\
\hline 22 & $55 / F$ & $\begin{array}{l}\text { Anti- } \\
\text { sintetase } \\
\text { Sd. }\end{array}$ & $\begin{array}{l}\text { CFA, PDN } 100 \text { mg/ } \\
\text { day }\end{array}$ & 975 & 7 & Lung & Cough, dyspnea & Improvement \\
\hline
\end{tabular}

CMV cytomegalovirus, SLE Systemic Lupus Erythematosus, SE Systemic sclerosis, Overlap syndrome Systemic Lupus Erythematosus + Systemic sclerosis + polymyositis, $R A$ rheumatoid arthritis, MPA microscopic polyangiitis, GPA granulomatosis with polyangiitis, $F$ Female, $M$, Male, AIRD autoimmune rheumatic disease, PDN Prednisone, AZA Azathioprine, MMF mycophenolate mofetil, CFA Cyclophosphamide (pulse), MP Methylprednisolone (pulse), MP + CFA combined pulse: methylprednisolone and cyclophosphamide. a: Maximum dose during hospitalization. b: methylprednisolone pulse $1 \mathrm{~g} / \mathrm{day}$ for 3 consecutive days 
Table 2 Demographic and clinical data of 22 patients with autoimmune rheumatic disease (AIRD) and positive cytomegalovirus antigenemia

\begin{tabular}{|c|c|}
\hline Female sex & $19(90 \%)$ \\
\hline Age (years) ${ }^{a}$ & $39.4 \pm 20.8$ \\
\hline \multicolumn{2}{|l|}{ AIRD } \\
\hline SLE & $13(59 \%)$ \\
\hline ANCA-associated Vasculitis & $4(18.2 \%)$ \\
\hline RA & $2(9 \%)$ \\
\hline Systemic sclerosis & $1(4.5 \%)$ \\
\hline Overlap syndrome & $1(4.5 \%)$ \\
\hline Anti-sintetase syndrome & $1(4.5 \%)$ \\
\hline Diagnosis AIRD ${ }^{\mathrm{b}}$ Time (months) & $10.5(0-276)$ \\
\hline \multicolumn{2}{|l|}{ Hospitalization cause $^{a}$} \\
\hline Activity + Infection & $11(50 \%)$ \\
\hline Infection only & $8(36.5 \%)$ \\
\hline Activity only & $3(13.6 \%)$ \\
\hline \multicolumn{2}{|l|}{ AIRD treatment } \\
\hline Maximum dose of corticosteroids in hospital (mg/ day) ${ }^{a}$ & $87.7 \pm 52.5$ \\
\hline Corticosteroids dose above $1 \mathrm{mg} / \mathrm{kg} /$ day $^{\mathrm{a}}$ & $19(86.4 \%)$ \\
\hline Methylprednisolone Pulse Therapy ${ }^{a}$ & $11(50 \%)$ \\
\hline Immunosuppressant medications $^{a}$ & $11(50 \%)$ \\
\hline \multicolumn{2}{|l|}{ Site of CMV infection ${ }^{a}$} \\
\hline Lung & $10(45.4 \%)$ \\
\hline Cytopenia & $9(40.9 \%)$ \\
\hline Gastrointestinal tract & $6(27.3 \%)$ \\
\hline Hospitalization time ${ }^{a}$ (days) & $41.9 \pm 34.1$ \\
\hline Hospitalization time until CMV-Ag be requested ${ }^{\mathrm{a}}$ (days) & $11.5 \pm 12$ \\
\hline Time of symptoms until CMV-Ag be requested ${ }^{\mathrm{a}}$ (days) & $7.8 \pm 7.1$ \\
\hline Time from the first positive CMV-Ag to specific treatment be started (days) & $3.3 \pm 3.1$ \\
\hline \multicolumn{2}{|l|}{ Number of positive CMV-Ag nuclei after specific treatment } \\
\hline With Ganciclovir ${ }^{\mathrm{b}}$ & $15(1-500)$ \\
\hline No ganciclovir ${ }^{b}$ & $7(1-4)$ \\
\hline Co-Infections ${ }^{a}$ & $16(72.7 \%)$ \\
\hline Polymicrobial Infections & $5(22.7 \%)$ \\
\hline CMV reactivation during hospitalization & 0 \\
\hline Prophylaxis after standard Ganciclovir treatment & 0 \\
\hline
\end{tabular}

${ }^{\mathrm{a}}$ Mean \pm standard deviation; ${ }^{\mathrm{b}}$ Median (minimum and maximum); AIRD Autoimmune Rheumatic Diseases, CMV-Ag cytomegalovirus antigenemia, SLE Systemic Lupus Erythematosus, RA Rheumatoid Arthritis

Regarding absolute CMV-Ag, three (13.6\%) patients had values above five cells and eight patients (36.4\%) had values above 10 cells. However, none of these two cutoffs CMV-Ag had significant association with death or poor outcome.

\section{Discussion}

Our data showed high incidence of positive CMV-Ag in hospitalized patients with AIRD, as well as severe disease severity and poor prognosis, including death.
To our the best knowledge, this is the first study to highlight the incidence of positive CMV-Ag in hospitalized patients with severe AIRD, especially SLE and ANCA-associated vasculitis. Thus, it could not be compared with another retrospective studies no incidence data and heterogeneous prevalence (from 2 to $50 \%$ ) $[4,8,15,16]$.

In addition to severity and high disease activity, it is worthy emphasizing that high doses of corticosteroids may have impaired the immune response in our patients $[4,17,28]$. Considering that over $95 \%$ of general 
Table 3 Comparison of clinical and demographic characteristics of patients with positive cytomegalovirus antigenemia according to the outcome: survivor or death

\begin{tabular}{|c|c|c|c|}
\hline & $\begin{array}{l}\text { Death } \\
n=10\end{array}$ & $\begin{array}{l}\text { Survivor } \\
n=11\end{array}$ & $p$ \\
\hline Age $^{\mathrm{b}}$ (years) & $44.3 \pm 23.4$ & $35.5 \pm 18.3$ & 0.32 \\
\hline Lymphocyte Count $(/ \mu \mathrm{L})^{\mathrm{b}}$ & $447.2 \pm 368.2$ & $870.3 \pm 692.9$ & 0.06 \\
\hline CMV-Ag ${ }^{\mathrm{b}, \mathrm{c}}$ & $113 \pm 205,2$ & $29 \pm 52.9$ & 0.67 \\
\hline Oral glucocorticosteroids (mg/ day) $)^{a, b}$ & $107 \pm 55.4$ & $71.7 \pm 46.3$ & 0.07 \\
\hline \multicolumn{4}{|l|}{ Methylprednisolone Pulse Therapy, n } \\
\hline Yes & $3(30 \%)$ & $8(72.2 \%)$ & \multirow[t]{2}{*}{0.19} \\
\hline No & $7(70 \%)$ & $4(36.6 \%)$ & \\
\hline Hospitalization time ${ }^{b}$ & $24.3 \pm 23.9$ & $56.6 \pm 35.1$ & 0.017 \\
\hline Hospitalization time until CMV-Ag be requested (days) ${ }^{b}$ & $9.9 \pm 14$ & $12.9 \pm 10.5$ & 0.42 \\
\hline Time of symptoms until CMV-Ag be requested (days) ${ }^{\mathrm{b}}$ & $7.9 \pm 8.2$ & $7.8 \pm 6.4$ & 0.77 \\
\hline Time from the first positive CMV-Ag to specific treatment be started (days) ${ }^{b}$ & $3.4 \pm 2.6$ & $3.3 \pm 3.7$ & 0.54 \\
\hline \multicolumn{4}{|l|}{ CMV suspicious cause, $\mathrm{n}$} \\
\hline Cytopenia & $2(20 \%)$ & $4(36.4 \%)$ & \\
\hline Cytopenia e GIT & $0(0)$ & $1(9.1 \%)$ & \\
\hline GIT & $2(20 \%)$ & $3(27.3 \%)$ & \multirow[t]{3}{*}{0.59} \\
\hline Pneumonia & $4(40 \%)$ & $4(36.3 \%)$ & \\
\hline Cytopenia e Pneumonia & $2(20 \%)$ & $0(0)$ & \\
\hline
\end{tabular}

CMV-Ag: cytomegalovirus antigenemia, $b$ mean \pm standard deviation, $c$ cels / 200.000polimorphonuclear. ${ }^{a}$ Maximum corticosteroid dose during hospitalization. GIT gastrointestinal tract. Cutoff value of 10 positive cores for CMV antigenemia

population have immunological memory for CMV, likely these three aspects together could be involved for reactivation of latent viral infection $[4,12,17,18]$. On the other hand, other authors found no association between CMV infection and immunosuppressive medications, especially corticosteroids $[3,8,16]$.

The lung (45.5\%) was the organ with the highest suspect involvement by $\mathrm{CMV}$ infection in our patients, confirming that the viral reactivation data in tracheal aspirates from immunosuppressed patients must be the main pathophysiologic mechanism, as well as pneumonitis reports and respiratory failure $[21,22]$. However, it is important to state the possibility of pneumonia caused by multiple microbial agents. Cytopenia had the second place in frequency (40.9\%), unlike recent retrospective report of 105 patients with SLE and active CMV infection related $81 \%$ of patients with some cytopenia [23]. The simultaneous involvement of various organs can also occur in immunosuppressed patients and was observed in 3 (13.6\%) of our patients. Although the presence of cytopenia may constitute a simple and early warning for CMV infection in immunocompromised patients with AIRD, this finding was not specific, since it can also mean disease activity and toxicity to immunosuppressants.

Several mechanisms may explain the role of CMV and the onset of rheumatic disease or as a possible trigger, as well as its association with increased mortality in lupus patients [23]. Due to their broad cell tropism, CMV has great variety of clinical manifestations in immunocompromised patients and can even be confused with the disease activity [3, 12, 19, 23, 25]. At diagnosis of CMV infection, SLE patients had higher incidence of hematologic, joint and kidney activity. Unlike cytopenias, articular and kidney involvement did not usually occur in reactivation of CMV infection and may be useful for the differential diagnosis between both clinical scenarios (infection vs. disease activity) [23].

Tasai et al. (2012) showed SLE patients infected by CMV had higher scores of SLEDAI, poor prognosis and increased mortality [12]. Our data confirm these interesting epidemiological features, since more than half of patients with positive CMV-Ag had SLE, particularly with early-onset disease and were youth. Thus, these findings address the role of CMV as trigger, as well as by collaborating on innate immunity and dysfunction of humoral and cellular immune response $[4,15,24,26,27]$.

The diagnosis of CMV infection is not performed routinely by rheumatologists and there is no active search or specific treatment for patients with AIRD. Our study provides a new information about modern strategies headed for these patients. First of all, it is an alert to the presence of infection or co-infection with CMV, according to our high incidence of CMV-Ag in the first 10 days of hospitalization. Secondly, the red flag is the fast and sensible methodology for detecting suspicious cases of CMV infection in AIRD patients. Thirdly, the delay for 
requesting $\mathrm{CMV}-\mathrm{Ag}$ and the risk of severe disease severity and higher mortality rate.

There are well-established recommendations for screening, treatment and prevention of CMV infection in immunocompromised patients with other conditions, such as cancer, AIDS and transplants [5, 7-11, 20]. However, there are a lack of information about management of AIRD patients, highlighting the relevance of current study and supporting the necessity for the development of specific protocols in this scenario.

In 2008, Takizawa et al. suggested the cut-off of 11.2 cells/200,000/ neutrophils as a significant value for distinguishing symptomatic and asymptomatic infections as well as higher positive predictive value for CMV infection and mortality in patients with AIRD [16]. As there is no consensus about the significant number of cells for AIRD patients, we considered at least one cell for the first investigation associated to clinical findings (fever plus cytopenias and/ or pulmonary infiltrates and/ or gut lesions and/ or hepatitis). However, in further re-analyses with several cut-off points, including 5 and 10 cells, we did not also find a significant CMV-Ag cut-off. Thus, our data confirm that, regardless age, duration of symptoms, number of positive cells, viral involvement site, the simple presence of CMV-Ag was associated with severe illness and higher risk of death, especially in those with shorter hospital stay and higher dose of corticosteroids.

Considering that AIRD hospitalized patients have multiple and complicated medical conditions, such as systemic inflammation, co-infections and renal failure, it is very difficult to assure the real direct cause of death and the multifactorial aspects altogether may occur among themselves.

Nonetheless, our study has some limitations. Firstly, it is related to CMV-Ag definition itself, because we cannot be sure that the presence of only one positive cell could be indicative of CMV infection. Secondly, is related to sample size, lack of control group and the heterogeneity of autoimmune diseases. Thirdly, we should not generalize our findings for outpatient patients or systematically request CMV-Ag for all hospitalized patients without a clinical suspicion. In addition, it is important to state that in any suspected case is need to confirm the CMV disease by histopathological analysis, for instance.

Although the survival patients with DRAI have kept imunossupression, none of them reactivated CMV over time (mean follow-up time 2 years), even without receiving prophylactic treatment with ganciclovir as suggested by protocols for transplanted patients. These new data emphasize that specific protocols are necessary for establishing appropriate diagnosis, treatment and monitoring CMV status in patients with AIRD, including prospective randomized controlled trials.

\section{Conclusions}

Our data showed high incidence of CMV-Ag in AIRD hospitalized patients, particularly early-onset lupus, severe disease activity, and higher mortality. Thus, the possibility of CMV infection should be included in differential diagnosis in AIRD patients.

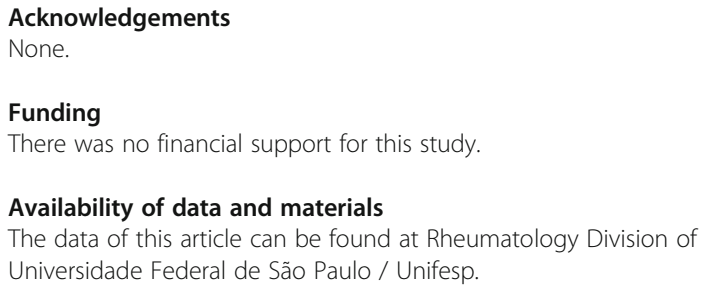

There was no financial support for this study.

Availability of data and materials

The data of this article can be found at Rheumatology Division of Universidade Federal de São Paulo / Unifesp.

\section{Author's contributions}

All authors made substantial contributions to the acquisition of data, have been involved in drafting the manuscript revising it critically and approved the final manuscript

Ethics approval and consent to participate

The study was approved by the Ethics and Research Committee of Hospital São Paulo / Unifesp (number 506.406).

Consent for publication

All the patients signed the informed consent form.

\section{Competing interests}

The authors declare that they have no competing interests.

\section{Publisher's Note}

Springer Nature remains neutral with regard to jurisdictional claims in published maps and institutional affiliations.

Received: 31 July 2018 Accepted: 16 April 2019

Published online: 14 May 2019

References

1. Azuma N, Hashimoto N, Yasumitsu A, Fukuoka K, Yokoyama K, Sawada H, et al. CMV infection presenting as a Cavitary lung lesion in a patient with systemic lupus erythematosus receiving immunosuppressive therapy. Inter Med. 2009;48:2145-9.

2. Baldanti F, Lilleri D, Gerna G. Use of the human cytomegalovirus (HCMV) antigenemia assay for diagnosis and monitoring of HCMV infections and detection of antiviral drug resistance in the immunocompromised. J Clin Virol. 1998;11:51-60.

3. Yamashita M, Ishii T, Iwama N, Takahashi H. Incidence and clinical features of cytomegalovirus infection diagnosed by cytomegalovirus pp65 antigenemia assay during high dose corticosteroid therapy for collagen vascular diseases. Clin Exp Rheumatol. 2006;24:649-55.

4. Hanaoka R, Kurasawa K, Maezawa R, Kumano K, Arai S, Fukuda T. Reactivation of cytomegalovirus predicts poor prognosis in patients on intensive immunosuppressive treatment for collagen-vascular diseases. Mod Rheumatol. 2012;22:438-45.

5. Kotton CN. Management of cytomegalovirus infection in solid organ transplantation. Nat Rev Nephrol. 2010;6:711-21.

6. Drew LW. Nonpulmonary manifestations of Cytomegalovirus infection in immunocompromised patients. Clin Microbiol Rev. 1992;5:204-10.

7. Emery V, Zuckerman M, Jackson G, Aitken C, Osman H, Pagliuca A, et al. Management of cytomegalovirus infection in haemopoietic stem cell transplantation. Br J Haematol. 2013;162:25-39.

8. Kotton CN, Kumar D, Caliendo AM, Åsberg A, Chou S, Snydman DR, et al. Internacional consensus guidelines on the Management of Cytomegalovirus in solid organ transplantation. Transplantation. 2010;89:779-95.

9. Andrews PA, Emery VC, Newstead C. Summary of the British Transplantation Society guidelines for the prevention and management of CMV disease after solid organ transplantation. Transplantation. 2011;92:1181-7. 
10. Whitley RJ, Jacobson MA, Friedberg DN, Holland GN, Jabs DA, Dieterich DT, et al. Guidelines for the treatment of Cytomegalovirus disease in patients with AIDS in the era of potent antiretroviral therapy. Arch Intern Med. 1998;158:957-69.

11. Lalonde RG, Bovivin G, Deschênes J, Hodge WG, Hopkins JJ, Klein AH. Et. al. Canadian consensus guidelines for the management of cytomegalovirus disease in HIV/AIDS. Can J Infect Dis Med Microbiol. 2004;15:327-35.

12. Tsai WP, Chen MH, Lee MH, Yu KH, Wu MW, Liou LB. Cytomegalovirus infection causes morbidity and mortality in patients with autoimmune diseases, particularly systemic lupus: in a Chinese population in Taiwan. Rheumatol Int. 2012;32:2901-8.

13. Gladman DD, Goldsmith $\mathrm{CH}$, Urowitz MB, Bacon P, Bombardier C, Isenberg $D$, et al. Crosscultural validation and reliability of three disease activity indices in systemic lupus erythematosus. J Rheumatol. 1992;19:608-11.

14. Mukhtyar C, Lee R, Brown D, Carruthers D, Dasgupta B, Dubey S, et al. Modification and validation of the Birmingham Vasculitis activity score (version 3). Ann Rheum Dis. 2009;68:1827-32.

15. Lesprit P, Scieux C, Lemann M, Carbonelle E, Moday J, Molina JM. Use of the Cytomegalovirus (CMV) Antigenemia assay for the rapid diagnosis of primary CMV infection in hospitalized adults. Clin Infect Dis. 1998;26:646-50.

16. Takizawa Y, Inokuma S, Tanaka Y, Saito K, Atsumi T, Hirakata M, Kameda H, et al. Clinical characteristics of cytomegalovirus infection in rheumatic diseases: multicentre survey in a large patient population. Rheumatology. 2008;47:1373-8.

17. Kutza AST, Hackstein EMH, Kirchner H, Bein G. High incidence of active Cytomegalovirus infection among septic patients. Clin Infect Dis. 1998;26:1076-82.

18. Fujimoto D, Matsushima A, Nagao M, Takakura S, Ichiyama S. Risk factors associated with elevated blood cytomegalovirus pp65 antigen levels in patients with autoimmune diseases. Mod Rheumatol. 2013;23:345-50.

19. Eisenstein $\mathrm{EM}$, Wolf DG. Cytomegalovirus infection in pediatric rheumatic diseases: a review. Pediatr Rheumatol. 2010;8:17.

20. Boeckh M, Boivin G. Quantitation of Cytomegalovirus: methodologic aspects and clinical applications. Clin Microbiol Rev. 1998;11:533-54.

21. Chilet M, Aguilar G, Benet I, Belda J, Tormo N, Carbonell JA, et al. Virological and immunological features of active cytomegalovirus infection in nonimmunosupressed pacientes in a surgical and trauma intensive care unit. J Med Virol. 2010;82:1884-391.

22. De Maar EF, Verschuuren EAM, Harmsen MC, The TH, Van Son WJ. Pulmonary involvement during cytomegalovirus infection in immunosuppressed patiens. Transpl Infec Dis. 2003;5:112-20.

23. Zhang J, Dou Y, Zhong Z, Su J, Xu D, Tang F, et al. Clinical characteristics and therapy exploration of active human cytomegalovirus infection in 105 lupus pacients. Lupus. 2014;0:1-9.

24. Nauclér CS. Autoimmunity induced by human cytomegalovirus in patients with systemic lupus erythematosus. Arthritis Res Ther. 2012;14:101-3.

25. Cunha BA, Gouzhva O, Nausheen S. Severe cytomegalovírus (CMV) community-acquired pneumonia (CAP) precipitaiting a systemic lúpus erytematosus (SLE) flare. Heart Lung. 2008;38:249-52.

26. Yoda Y, Hanaoka R, Ide H, Isozaki T, Matsunawa M, Yajima N, et al. Clinical evaluation of patients with inflammatory connective tissue diseases complicated by cytomegalovirus antigenemia. Mod Rheumatol. 2006;16:137-42.

27. Jih Su BY, Yu Su C, Fu Yu S, Jen Chen C. Incidental discovery of high systemic lupus erythematosus disease activity associated with cytomegalovirus viral activity. Med Microbiol Immunol. 2007;196:165-70

28. Mori T, Kameda H, Ogawa H, lizuka A, Sekiguchi N, Takei H, et al. Incidence of Cytomegalovirus reactivation in patients with inflammatory connective tissue diseases who are under immunosuppressive therapy. J Rheumatol. 2004;31:1349-51.

Ready to submit your research? Choose BMC and benefit from:

- fast, convenient online submission

- thorough peer review by experienced researchers in your field

- rapid publication on acceptance

- support for research data, including large and complex data types

- gold Open Access which fosters wider collaboration and increased citations

- maximum visibility for your research: over $100 \mathrm{M}$ website views per year

At BMC, research is always in progress.

Learn more biomedcentral.com/submissions 